\title{
GEOCHEMISTRY OF SOME BRAZILIAN RIVERS
}

\author{
LYCIA MARIA MOREIRA-NORDEMANN*
}

\begin{abstract}
Concentrations of the totality of the dissolved salts and sodium, calcium, potassium, magnesium, and uranium were measured in ten rivers belonging to three hydrografic basins located in Northeastern Brazil. Activity ratios $U^{234} / U^{238}$ were also measured. A correlation was done between the results obtained and the geological and climatic context of these regions. Sodium is the most abundant element in the waters, except for rivers flowing in calcareous regions for which calcium is predominant. The concentrations of the major cations are function of the regional lithology whereas water salinity depends on climatic factors.
\end{abstract}

RESUMO As concentraçðes de sais totais dissolvidos e de sódio, cálcio, potássio, magnésio e urânio foram determinadas nas águas de dez rios pertencentes a três diferentes bacias hidrográficas, situadas no nordeste do Brasil. Tenta-se uma correlação entre os resultados obtidos e o contexto geoclimático das regioes drenadas por tais rios. $O$ sódio é o elemento mais abundante nas águas, exceto no caso de rios banhando regiðes calcárias, em que o cálcio predomina. As concentraçðes em cátions maiores são funçâo da litologia regional enquanto a salinidade depende de fatores climáticos.

INTRODUCTION Rivers transport soluble and suspended matter down to the oceans. Transported matter has been extensively studied to give important information on geochemical and geological phenomena (Livingstone, 1963, Gibbs, 1972; Subramanian, 1979; Johnson et al., 1968, only to quote some examples). In particular, the measurement of uranium concentrations and of activity ratios $U^{234} / U^{238}$ provides a "fingerprint" of groundwater masses throught which mixing volumes and flowpatterns can be determined (Osmond et al., 1974).

In the present work, I measured concentrations of the totality of the dissolved salts and of $\mathrm{Na}, \mathrm{Ca}, \mathrm{K}, \mathrm{Mg}$ and also the activity ratios $\mathrm{U}^{234} / \mathrm{U}^{238}$, in waters from the rivers belonging to three different hydrografic basins located in northeastern Brazil. An attempt was made to relate the results obtained with the geology and climate of the regions drained by the rivers.

DATA AND METHODS Description of basins The rivers are located between $11^{\circ}$ and $14^{\circ}$ South latitude and between $38^{\circ}$ and $42^{\circ}$ West longitude, west of Salvador, capital city of the Bahia State, in Brazil. These rivers belong to three hydrografic basins: Paraguaçu, Almas and Pojuca. Localization of these basins are shown in Fig. 1. $P A R A G U A C U B A S I N$ It is without any doubt the most important of these basins, not only by its area $\left(56,500 \mathrm{~km}^{2}\right)$ but also by the volume of transported water: values between $6.60 \mathrm{~m}^{3} / \mathrm{s}$ and $153.27 \mathrm{~m}^{3} / \mathrm{s}$ for the river flowrate were measured between 1961 and 1967, after the data given by CEEB (Bahia Electric Energy Control).

The river Paraguaçu springs out in Serra de Sincorá (Barra da Estiva, $13^{\circ} 37^{\prime} \mathrm{S}$ lat, $41^{\circ} 20^{\prime} \mathrm{W}$ long), $300 \mathrm{~km}$ distant from the Atlantic coast, and flows to the Baía de Todos os Santos in the Atlantic Ocean. Its main tributaries are the rivers Santo Antônio, Jacuípe, Tupim, Piranhas, Capivari, Peixes and Piratigé.

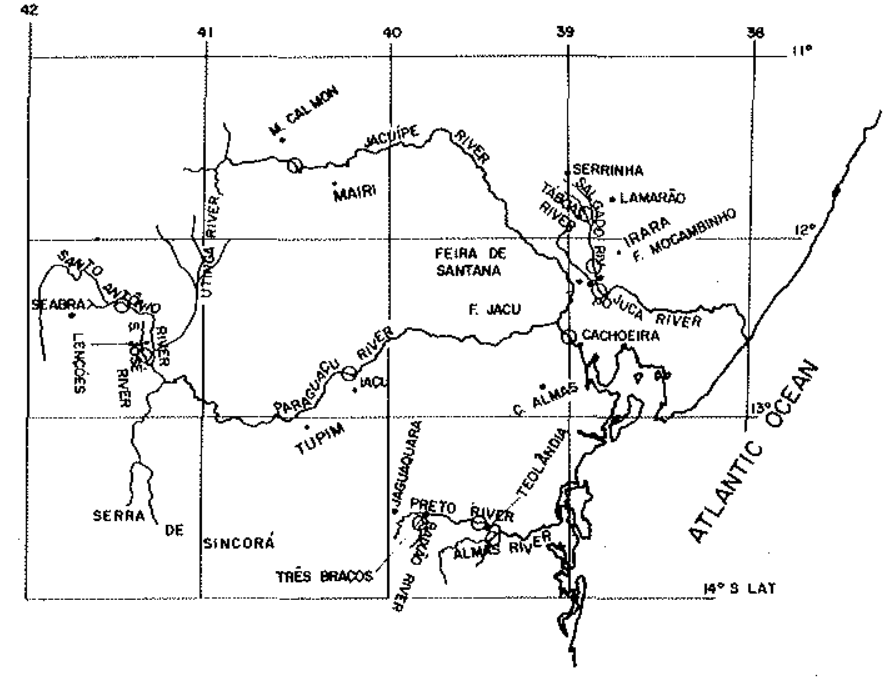

Figure 1-Map of the region showing the rivers studied and the water sampling points (O)

The mean pluviometry (obtained after 20 year observations, Andrea, 1963) at its origin is $1,042 \mathrm{~mm} / \mathrm{yr}$; it is irregular with 93 days of rain per year at Barra da Estiva. At Lençóis, the rainfall is $1,553 \mathrm{~mm} / \mathrm{yr}$, with 143 days/yr of precipitation. In the medium course, the rainfall is lower or equal to $700 \mathrm{~mm} / \mathrm{yr}$. (At Tupim, $100 \mathrm{~km}$ away from the spring, it rains just $472.2 \mathrm{~mm} / \mathrm{yr}$ within 30 days). The medium course comprises the greatest portion of this basin.

In the lower course, the rainfall turns anew to be greater than $1,000 \mathrm{~mm} / \mathrm{yr}$ of regular precipitation through the year $(1,044 \mathrm{~mm} / \mathrm{yr}$ at São Félix).

* Instituto de Pesquisas Espaciais (INPE), Conselho Nacional de Desenvolvimento Científico e Tecnológico (CNPq), CEP 1220u, São José dos Campos, SP, Brasil 
This basin was extensively studied by Tricart and Cardoso Silva (1968) who divided it in three regions: the first one, the high course where the relief is more pronounced on the eastern side of the Serra de Sincorá, with altitudes greater than $1,000 \mathrm{~m}$, with influence on the climate which is more humid. From the geological point of view, quartzites dominate in the region of the spring of Paraguaçu River, with quartz veins and with fine and clayish sandstones. Along the higher Santo Antonio basin, the sediments of the Bambuí group, mainly calcareous, are found up to the Chapada where the gnaisses of the Precambrian shield predominate besides quartzites and sandstones. This second region is a great plateau, at an altitude around $900 \mathrm{~m}$ where flows the major part of the medium course of the Paraguaçu River. It is a region of caatinga and cerrados, with shrubby and scarce vegetation. On the left bank and near the end of the medium course, the Paraguaçu receives the Jacuipe River which drains mainly metamorphic rocks of the Precambrian shield through a semi-arid region.

At last, in the lower basin, the Paraguaçu crosses the Reconcavo sedimentary graben, which shows a sucession of valleys and of rounded hills. The graben is fulfilled by the Barreiras Group composed mostly of clastic material (detritic facies) varying from pebbles to sand or clay. There are iron oxides in various quantities appearing as crust or as concretions or enriching the sediments. This region is crossed through by all the major rivers of the three studied basins at the end of their course: Paraguaçu, Almas and Pojuca.

ALMAS RIVER BASIN The Almas River, also named Jequié, springs out at Apuarema (13 ${ }^{\circ} 55^{\prime} \mathrm{S}$ lat, $39^{\circ} 45^{\prime} \mathrm{W}$ long) in the Serra Geral, $120 \mathrm{~km}$ far from the Atlantic Ocean. Its basin extends over an area of about $2,000 \mathrm{~km}^{2}$. At the end part of its medium course (and at an altitude of $150 \mathrm{~m}$ ), the Almas River receives its main tributary, the Preto River, which springs out at Jaguaquara, at about $45 \mathrm{~km}$ far away from the Almas River source.

From the geological point of view, these two basins are very homogeneous: they drain the Precambrian formation where the metamorphic rocks dominate, mainly granulites and charnockites. In the high and medium course of Almas River gneisses were also found.

The relief is irregular in the higher and medium basin of the Almas River and in the entire Preto River basin, with altitudes greater than $600 \mathrm{~m}$, showing a succession of "half orange" shaped round hills. After Tricart and Cailleux (1974), the observed relief is due to a strong chemical weathering and lower activity of the river, in a region where humid climate dominated for long periods. The vegetation is typically the luxuriant hygrophilic forest, which is spread all over the basin.

Through its lower course, the Almas River flows over the sedimentary formations of the Recôncavo.

The rainfall varies around $700 \mathrm{~mm} / \mathrm{yr}$ near the sources of these two rivers and goes up over a short distance to greater than $1,000 \mathrm{~mm} / \mathrm{yr}$, regularly distributed $(1,291$ $\mathrm{mm} / \mathrm{yr}$ within 225 days/yr at Gandu). Unfortunately we have no data on the Almas River flow rate, but we already know that the mean flow of the Preto River just before its confluence point is $10.34 \mathrm{~m}^{3} / \mathrm{s}$, which indicates that Almas River is expected to have a higher flow rate than this value.
A detailed study of the Preto River basin was performed previously (Moreira-Nordemann, 1977).

POJUCA RIVER BASIN This river springs out at Sta. Bárbara (11 ${ }^{\circ} 55^{\prime} \mathrm{S}$ lat, $39^{\circ} \mathrm{W}$ long) in the middle of Norteasthern Brazil where runs its high and part of its medium course. All the rocks are metamorphic, mainly gneisses (biotite gneisses, augen gneiss with and without hornblend, granitized gneiss). There are also anatexic granites, amphibolites and quartzites. The Pojuca River and also its left bank tributary, the Salgado River, run nearby the tectonic faults of the Reconcavo, that the Pojuca River crosses in its lower course, far after having received its tributary the Salgado River.

The medium and high basin of the Pojuca River and the entire Salgado River basin are located in a plateau at a mean altitude of $250 \mathrm{~m}$. The vegetation is shrubby, scarce and drought-resistant. The rainfall is $855.8 \mathrm{~mm} / \mathrm{yr}$ at Serrinha in the north and near the source of the Pojuca River and $992 \mathrm{~mm} / \mathrm{yr}$ at Irará at the confluence point with the Salgado River (the Táboas River is itself a tributary of the Salgado River in its high course). The rainfall distribution is meanwhile very irregular.

In its low course, the Pojuca River drains the Recôncavo, a region with high pluviometry: $1,416.3 \mathrm{~mm} / \mathrm{yr}$ at Catu and $1,734.1 \mathrm{~mm} / \mathrm{yr}$ at Santo Amaro. The Pojuca River appears to be directly influenciated by the climate of the regions it runs over: it is narrow and shallow in its high and medium basin, wide and deep in its low basin, where the rainfall rates are low and high respectively. These data are summarized in Table 1.

Experimental methods The 20 to 40 liters samples of water were acidified at the place of collection and carried to the laboratory where the analyses were performed. In the particular case of the Preto River, systematic sampling was performed to obtain samples corresponding to different flow rates.

The concentration of $\mathrm{Na}, \mathrm{Ca}, \mathrm{K}$ and $\mathrm{Mg}$ were measured by atomic absorption spectrometry, using a model 303 Perkin-Elmer spectrometer. The precision is $\pm 5 \%$. This kind of analysis is a classical one (Slavin, 1968; Pinta et al., 1971).

The determination of the concentrations of the totality of the dissolved salts in the samples of filtrated water was made by the gravimetric method as described by Rodier (1971): a volume of $100 \mathrm{ml}$ is heated in a porcelain crucible in a water bath to dryness and then dried in a heater at $110^{\circ} \mathrm{C}$ during 4 hours and cooled during 15 min in a desiccator before weighing. This process gives a precision of about $1 \%$ on the salt concentration but it must be reminded that some systematic error may not be eliminated due to hygroscopic properties of the evaporated salts, to interstitial or crystalization water remaining after drying at $100^{\circ} \mathrm{C}$.

Uranium concentrations and $\mathrm{U}^{234} / \mathrm{U}^{238}$ activity ratios in water samples have been measured by means of a $\mathrm{U}^{232}$ tracer and alpha-ray spectrometry after chemical treatment (Moreira-Nordemann, 1977): 10-30 liters of water sample were used. U was first concentrated on activated vegetal charcoal, after addition of $U^{232}$ tracer and hexamethylene tetramine. After filtration and calcination, the residue containing $U$ is dissolved in $8 \mathrm{~N} \mathrm{HCl}$ and passed through the Dowex 1X8-100/200 mesh anion ex- 
Table 1 - Summarized data of the studied basins and sampling points (showed in Fig. I)

\begin{tabular}{|c|c|c|c|}
\hline & Rivers & $\begin{array}{l}\text { Sampling } \\
\text { location }\end{array}$ & Summarized data \\
\hline \multirow{5}{*}{ 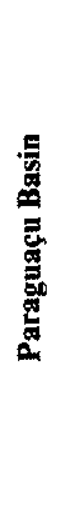 } & São José & $\begin{array}{l}\text { Near } \\
\text { Lençóis }\end{array}$ & $\begin{array}{l}\text { Tropical humid climate. Mean rainfall } 1,553 \mathrm{~mm} / \mathrm{yr} \text { at Lençóis. } \\
\text { Metamorphic rocks mainly quartzites. }\end{array}$ \\
\hline & $\begin{array}{c}\text { Sto. } \\
\text { Antônio }\end{array}$ & $\begin{array}{c}\text { Near } \\
\text { Seabra }\end{array}$ & $\begin{array}{l}\text { Mean rainfall } 885 \mathrm{~mm} / \mathrm{yr} \text { at Seabra. } \\
\text { Calcareous region with sandstones veins. }\end{array}$ \\
\hline & Jacuípe & $\begin{array}{l}\text { Near } \\
\text { M. Calmon }\end{array}$ & $\begin{array}{l}\text { Semi-arid region. Pluviometry around } 700 \mathrm{~mm} / \mathrm{yr} \text { in this region }(772 \mathrm{~mm} / \mathrm{yr} \text { at Mairi). } \\
\text { Irregular. Metamorphic rocks mainly gnaisses and quartzites. }\end{array}$ \\
\hline & Paraguaçu & Iaçu & $\begin{array}{l}\text { Mean basin. Precipitation at Tupim: } 472 \mathrm{~mm} / \mathrm{yr} \text {. Caatingas and cerrados. } \\
\text { Metamorphic rocks mainly gnaisses and quartzites. }\end{array}$ \\
\hline & Paraguaçu & $\begin{array}{l}\text { Cachoeira } \\
\text { (S. Félix) }\end{array}$ & $\begin{array}{l}\text { Lower, basin, Recôncavo region, sedimentary, humid. } \\
\text { Precipitation at S. Félix: } 1,044 \mathrm{~mm} / \mathrm{yr} \text {. }\end{array}$ \\
\hline \multirow{3}{*}{ 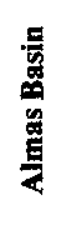 } & Baixão & Três Braços & \multirow{3}{*}{$\begin{array}{l}\text { Tropical humid climate, without dry season. Mean rainfall } 1,016 \mathrm{~mm} / \mathrm{yr} \text { for this } \\
\text { basin }(700 \mathrm{~mm} / \mathrm{yr} \text { at Jaguaquara, but } 1,619 \mathrm{~mm} / \mathrm{yr} \text { at Teolandia). } \\
\text { Granulites and charnockites dominate in the whole basin, but gnaisses were also found } \\
\text { in higher } \\
\text { Almas basin. }\end{array}$} \\
\hline & Preto & Teolândia & \\
\hline & Almas & $\begin{array}{l}\text { Rio das Almas } \\
\text { (Village) }\end{array}$ & \\
\hline \multirow{3}{*}{ 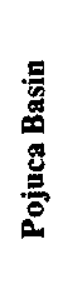 } & Táboas & $\begin{array}{c}\text { Near } \\
\text { Lamarão }\end{array}$ & \multirow{3}{*}{$\begin{array}{l}\text { Semi-arid region. Mean rainfall greater than } 800 \mathrm{~mm} / \mathrm{yr}(992 \mathrm{~mm} / \mathrm{yr} \text { at Irará), but } \\
\text { irregularly distributed, with long drought periods. } \\
\text { Metamorphic rocks, mainly gnaisses. }\end{array}$} \\
\hline & Salgado & $\begin{array}{c}\text { Faz. } \\
\text { Mocambinho }\end{array}$ & \\
\hline & Pojuca & $\begin{array}{l}\text { Faz. } \\
\text { Jacu }\end{array}$ & \\
\hline
\end{tabular}

change resin column, to separate from iron by disopropyl ether extraction. The uranium recovered ar $\lrcorner$ purified by this way is deposited on a stainless stee' disc with TTA (thenoyltrifluor-acetone). $\mathrm{U}^{238}$ concentration is calculated from the ratio of the counting rates of $U^{238}$ and $U^{232}$ peaks, and the quantity of $U^{232}$ introduced as a tracer. Analytical techniques in measuring uranium concentrations and $\mathrm{U}^{234} / \mathrm{U}^{238}$ activity ratios and treatment of data are reported in detail by Osmond and Cowart (1976).

RESULTS Table II presents the concentrations of the totality of the salts (anions and cations) and the $\mathrm{Na}, \mathrm{Ca}$, $\mathrm{K}, \mathrm{Mg}$ and $\mathrm{U}$ concentrations in the water of the studied rivers. The activity ratio $\mathrm{U}^{234} / \mathrm{U}^{238}$ for each sample also appears in this table.

The concentrations of the elements and of the totality of the dissolved salts in the river waters include the atmospheric contribution carried by rain water and also the contributions in soluble elements coming from the chemical weathering of rocks.
The rivers which show the highest salinities are Jacuípe, Pojuca, Salgado and Taboas rivers, the three last ones belonging to the same basin. The Pojuca River water was sampled at Fazenda Jacu, before the rivers enter the sedimentary Reconcavo region. So, the lithology of the regions crossid over by these rivers is alike; being constitued of metamorphic rocks where gnaisses predominate.

Another common point between the four rivers with high concentrations of salts is the climatic-pluviometric factor in the Salgado and Táboas basins, and in the high and medium Pojuca and Jacuípe basins, where the samples were taken: all these rivers run through semi-arid regions in Northeastern Brazil, with irregular rainfall distribution and very high evaporation rate. The Táboas River is of intermittent nature, a common feature among other rivers in this region.

The high salinity of the rivers of Northeastern Brazil is well known: Anjos and Bastos (1968) found a concentration of $1.55 \mathrm{~g} / 1$ salts for the Inhambupe River and 2.77 $\mathrm{g} / \mathrm{l}$ for the Jacuípe River. Several studies were performed on this subject and also on the increase of salinity of underground waters of Northeastern Brazil. Among them we may quote Kreysing et al. (1973) and Cruz (1974). 
The high concentrations for the total dissolved salts was previously studied (Moreira-Nordemann and Nordemann, 1980) in detail for the Salgado River basin: high evaporation and irregular pluviometry seem to us to be the factors which are directly responsible for such phenomenon: during long periods of drought, superficial waters are fed by underground waters which already present high concentrations of salts. On the other side, the high evaporation which exists in the region tends to "concentrate" the elements brought by rain water which after re" dissolution and underground infiltration contribute to the high concentration of salts, this cycle being repeated long period.

After the mean values calculated by Livingstone (1963) the Southamerican rivers seem to be richer in $\mathrm{Ca}$ than in $\mathrm{Na}$. Gibbs (1972) measured a concentration of $6.5 \mathrm{mg} / 1$ for $\mathrm{Ca}$ and $3.1 \mathrm{mg} / \mathrm{l}$ for $\mathrm{Na}$ in the Amazon River. In the case of the rivers I studied in this work, with only two exceptions, $\mathrm{Na}$ is the most abundant element in the river's water. $\mathrm{Na}$ is, de facto, a very mobile ion which is easily lixiviated.

Calcium is more abundant than the three other measured elements in the water of the Santo Antônio River and of the medium course of Paraguaçu River. This is certainly due to the fact of crossing the Bambuí group sediments which are mainly calcareous (the same does not happen for its tributary, the São José River which runs over quartzites). Limestone comes in solution from the region drained by Utinga River (tributary of Santo Antônio River) and from the Chapada crossid over by the Paraguaçu River, as it was suggested by Tricart and Cardoso da Silva (1968). Later on, in the lower course, at Cachoeira, the Paraguaçu River shows highest $\mathrm{Na}$ contents, due to the contributions from the other tributaries (mainly the Jacuípe River), and for having already crossed through crystalline rocks, mainly metamorphic rocks.

Measurements of sodium and calcium concentrations in rain water were performed during two years in the $\mathrm{Pa}$ raguaçu basin by Ribeiro Filho (1975). The mean values obtained show that $\mathrm{Na}$ concentrations in rain water are higher than $\mathrm{Ca}$ concentrations, well in the higher basin as in the lower one: $0.25 \mathrm{mg} / \mathrm{l}$ of $\mathrm{Na}$ and $0.16 \mathrm{mg} / \mathrm{l}$ of $\mathrm{Ca}$ at Lençóis, and $0.68 \mathrm{mg} / 1$ of $\mathrm{Na}$ and $0.10 \mathrm{mg} / 1$ of $\mathrm{Ca}$ at Cruz das Almas. These results confirm that the high $\mathrm{Ca}$ contents found in the Santo Antonio River and in the $\mathrm{Pa}$ raguaçu River at Iaçu are due only to the calcareous rocks found in these regions.

The concentrations of $\mathrm{K}$ and $\mathrm{Mg}$ are relatively low. The retention of $\mathrm{K}$ by the biomass and by soils has been shown previously (Johnson et al., 1968; MoreiraNordemann, 1978). The same fact also happens frequently for $\mathrm{Ca}$. Magnesium is, in general, easily lixivia-

Table $2-\mathrm{Na}, \mathrm{Ca}, \mathrm{K}, \mathrm{Mg}$ and $U$ concentrations for river water. Total salt contents and activity ratio ${ }^{234} U^{238} U$

\begin{tabular}{|c|c|c|c|c|c|c|c|c|c|c|}
\hline & \multirow{2}{*}{ Rivers } & \multirow{2}{*}{$\begin{array}{l}\text { Sampling } \\
\text { location }\end{array}$} & \multirow{2}{*}{$\begin{array}{c}\text { Total } \\
\text { salts } \\
(\mathrm{mg} / \mathrm{l})\end{array}$} & \multirow{2}{*}{$\underset{(\mathrm{mg} / \mathrm{l})}{\mathrm{Na}}$} & \multirow{2}{*}{$\underset{\mathrm{mg} / \mathrm{I}}{\mathrm{Ca}}$} & \multirow{2}{*}{$\underset{\mathbf{m g} / \mathbf{I}}{\mathrm{K}}$} & \multirow{2}{*}{$\begin{array}{c}\mathrm{Mg} \\
(\mathrm{mg} / \mathrm{l})\end{array}$} & ${ }^{234} U$ * & \multirow{2}{*}{$\begin{array}{l}\mathbf{U} * * \\
\mu \mathbf{g} / \mathbf{l}\end{array}$} & \multirow{2}{*}{$\begin{array}{c}\text { Date of } \\
\text { sampling } \\
1973\end{array}$} \\
\hline & & & & & & & & ${ }^{238} \mathbf{U}$ & & \\
\hline \multirow{5}{*}{ 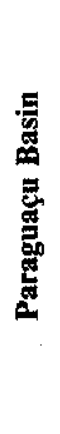 } & São José & Lençóis & 44 & 11.7 & 4.7 & 2.00 & 2.3 & $1.7 \pm 0.1$ & 0.08 & $15 / 10$ \\
\hline & Sto. Antônio & $\begin{array}{c}\text { Near } \\
\text { Seabra }\end{array}$ & 140 & 5.4 & 21.0 & 2.20 & 8.5 & $3.4 \pm 0.2$ & 0.23 & $15 / 10$ \\
\hline & Jacuipe & $\begin{array}{c}\text { Near } \\
\text { M. Calmon }\end{array}$ & 440 & 92.0 & 40.0 & 23.75 & 34.4 & $1.98 \pm 0.05$ & 0.05 & $11 / 11$ \\
\hline & Paraguaçu & Iaçu & 20 & 2.2 & 3.9 & 0.55 & 2.0 & $1.68 \pm 0.04$ & 0.17 & $06 / 09$ \\
\hline & Paraguaçu & $\begin{array}{l}\text { Cachoeira } \\
\text { (S. Félix) }\end{array}$ & 45 & 6.9 & 4.4 & 0.95 & 3.0 & $1.72 \pm 0.02$ & 0.20 & $08 / 09$ \\
\hline \multirow{2}{*}{ 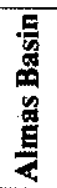 } & Baixão & Três Braços & 69 & 21.7 & 2.7 & 17.40 & 2.5 & $1.13 \pm 0.05$ & 0.03 & $18 / 08$ \\
\hline & Almas & $\begin{array}{l}\text { R. das Almas } \\
\text { (Village) }\end{array}$ & 31 & 7.8 & 3.7 & 1.70 & 2.4 & $1.3 \pm 0.1$ & 0.07 & $11 / 12$ \\
\hline \multirow{3}{*}{ 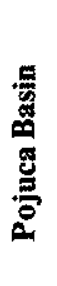 } & Táboas & $\begin{array}{c}\text { Near } \\
\text { Lamarão }\end{array}$ & 15,600 & 4,131 & 645 & 17 & 1,337 & $1.47 \pm 0.02$ & 13.61 & $21 / 11$ \\
\hline & Salgado & $\begin{array}{c}\text { Faz. } \\
\text { Mocambinho }\end{array}$ & 10,380 & 2,350 & 607 & 50 & 850 & $1.50 \pm 0.03$ & 9.24 & $14 / 09$ \\
\hline & Pojuca & $\begin{array}{l}\text { Faz. } \\
\text { Jacu }\end{array}$ & 2,020 & 700 & 130 & 100 & 109 & $1.47 \pm 0.03$ & 1.50 & $08 / 11$ \\
\hline
\end{tabular}

* Uncertainty corresponding to $1 \sigma$

$* *$ Uncertainty $\pm 5 \%$ corresponding to $1 \sigma$ 
Table $3-\mathrm{Na}, \mathrm{Ca}, \mathrm{K}, \mathrm{Mg}$ and total salt concentrations in Preto River water, collected systematically at Teolandia, and for different flowrates

\begin{tabular}{c|c|c|c|c|c|c|c|c|c|c}
\hline $\begin{array}{c}\text { Sample } \\
\text { number }\end{array}$ & $\begin{array}{c}\text { Date of } \\
\text { sampling } \\
\mathbf{1 9 7 3}\end{array}$ & $\begin{array}{c}\text { Flow } \\
\mathbf{r a t e} \\
\mathbf{m}^{3} / \mathbf{s}\end{array}$ & $\begin{array}{c}\text { Total } \\
\mathbf{s a l t s} \\
\mathbf{m g} / \mathbf{I}\end{array}$ & $\begin{array}{c}\mathbf{N a} \\
\mathbf{m g} / \mathbf{I}\end{array}$ & $\begin{array}{c}\mathbf{C a} \\
\mathbf{m g} / \mathbf{l}\end{array}$ & $\begin{array}{c}\mathbf{K} \\
\mathbf{m g} / \mathbf{1}\end{array}$ & $\begin{array}{c}\mathbf{M g} \\
\mathbf{m g} / \mathbf{l}\end{array}$ & $\mathbf{C a} / \mathbf{N a}$ & $\mathbf{K} / \mathbf{N a}$ & $\mathbf{M g} / \mathbf{N a}$ \\
\hline P10 & $14 / 11$ & 7.59 & 48 & 11.7 & 2.0 & 1.9 & 1.8 & 0.17 & 0.16 & 0.15 \\
\hline P1 & $12 / 08$ & 8.63 & 54 & 14.8 & 2.9 & 2.1 & 2.3 & 0.20 & 0.14 & 0.16 \\
\hline P5 & $22 / 09$ & 9.68 & 74 & 12.0 & 2.2 & 1.9 & 1.8 & 0.18 & 0.16 & 0.15 \\
\hline P13 & $11 / 12$ & 14.8 & 29 & 12.4 & 2.7 & 2.4 & 1.8 & 0.22 & 0.19 & 0.15 \\
\hline P12 & $07 / 12$ & 25.7 & 28 & 11.2 & 2.5 & 2.5 & 1.9 & 0.22 & 0.22 & 0.17 \\
\hline P11 & $01 / 12$ & 66.9 & 34 & 5.1 & 1.0 & 2.9 & 1.0 & 0.20 & 0.57 & 0.20 \\
\hline
\end{tabular}

ted, but rocks are much poorer in $\mathrm{Mg}$ than in the other three measured elements. Baixão River is the only one that have relatively high $\mathrm{K}$ concentration.

Table 3 presents the $\mathrm{Na}, \mathrm{Ca}, \mathrm{K}$ and $\mathrm{Mg}$ concentrations and the ratios $\mathrm{Ca} / \mathrm{Na}, \mathrm{K} / \mathrm{Na}$ and $\mathrm{Mg} / \mathrm{Na}$ in the waters of the Preto River (tributary of the Almas River) for differents flow rates and various dates of sampling.

Excepting the result relative to the highest measured flow $\left(66.9 \mathrm{~m}^{3} / \mathrm{s}\right)$, we may note that the concentrations of $\mathrm{Na}, \mathrm{Ca}, \mathrm{K}$ and $\mathrm{Mg}$ vary only little as a function of the flow rate. These elements are present in rain water in very variable amounts (Ribeiro Filho, 1975): as an example we may quote that $\mathrm{Ca}$ concentrations vary between 0.01 and $0.97 \mathrm{mg} / \mathrm{l}$ in rain water at Jaguaquara. Na concentrations vary between 0.02 and $1.18 \mathrm{mg} / \mathrm{l}$, that of $\mathrm{K}$ vary between 0.03 and $0,41 \mathrm{mg} / 1$ and the variation is between 0.02 and $0.22 \mathrm{mg} / \mathrm{l}$ for $\mathrm{Mg}$ at the same place. However, due to a fluvio-pluviometric regularity which is characteristic of this basin, the variations of the concentrations are relatively weak, which is confirmed by the approximate constancy of the ratios $\mathrm{Ca} / \mathrm{Na}, \mathrm{K} / \mathrm{Na}$ and $\mathrm{Mg} / \mathrm{Na}$. The geochemical budget of the basin of the Preto River (MoreiraNordemann, 1978) has shown that rain water contribution is $24 \%$ of the concentration of $\mathrm{Na}$ and $\mathrm{Mg}$ found in the river water. For $\mathrm{Ca}$ and $\mathrm{K}$, rain water contributions are $26 \%$ and $19 \%$ respectively.

Table 3 also presents the total dissolved salts (cations and anions) for samples of Preto River's water taken at different flow rates. These salts also include (as for results shown in Table 2) the elements in solution from the chemical weathering of rocks and those brought by rain water. The total salt concentrations vary in function of the flow rate. They increase slightly up to the mean flow rate and decrease for higher ones.

The $U$ concentrations in river water (Table 2 ) are higher for the three rivers which have higher salinity, and this had to be expected. U is "concentrated" by evaporation as it happens for any other element. However, for the rest of the rivers, a direct proportionality between the concentrations of $U$ and that of the salts does not exist. For instance, the Santo Antônio River is richer in $U$ than the Jacuipe even though the latter is four times "saltier" than the first one is. $U$ concentrations in lixiviated waters seem to be a function of $U$ content in minerals of the rocks and of the kind of these minerals (MoreiraNordemann, 1977).

Uranium concentrations were determined for various flow rates of Preto River (Moreira-Nordemann, 1980) and it was seen that $U$ is diluted for high flow rates, which is justified because $U$ is not present in rain water.

The activity ratios $\mathrm{U}^{234} / \mathrm{U}^{238}$ is a characteristic of each basin and pratically individualize it as a kind of fingerprint. The highest activity ratios $\mathrm{U}^{234} / \mathrm{U}^{238}$ are shown by the rivers of the Paraguaçu basin. Then, after come those of the Pojuca basin and at the end, those of Almas basin. This ratio was found to be always greater than one, which confirms, one more time the preferential solution of $U^{234}$ on regard to $U^{238}$. The activity ratio $\mathrm{U}^{234} / \mathrm{U}^{238}$ has been used in hydrological studies to characterize the origin and the distribution of aquifers (Osmond et al, 1974; Adrews and Kay, 1978).

CONCLUSIONS For the three studied basins, the concentrations of salts in the water of the rivers seem to be mainly a function of the climatic conditions of the regions, being strongly modulated by the pluviometric factors and by evaporation. The rivers running in semi-arid regions present higher concentrations of salts.

The major cations ( $\mathrm{Na}, \mathrm{Ca}, \mathrm{K}$ and $\mathrm{Mg}$ ) concentrations measured in the water of the rivers are directly influenced by the lithology of the region. $\mathrm{Na}$ is always the mosi abundant element, except for rivers running in calcareous regions, where $\mathrm{Ca}$ is the most abundant one. $\mathrm{K}$ is among four cations measured, the one that presents the lower concentration, including when rivers have high concentration of total salts. It is without any doubt the prefered element of the biomass and it is retained also by the clay formed during the weathering process, from which it is not easily lixiviated.

There is no evidence of a direct proportionality between the $U$ concentrations and that of the totality of dissolved salts.

The values of $U^{234} / \mathrm{U}^{238}$ activity ratios are characteristic of each basin and serve to characterize the rivers of any one of these basins. 


\section{REFERENCES}

ANJOS, N.R.F. dos and BASTOS, C.A. de M. - 1968 - Estudo das possibili dades hidrológicas de Feira de Santana - Bahia. Sudene, Div. Doc. Hidrogeolog. $n$. 20 Recife.

ANDREA, R. - 1963 - Chuvas na Bahia. M.V.O.P.-D.N.O.C.S.-C.P.E. Salva dor, BA, Brasil.

ANDREWS, J.N. and KAY, R.L.F. - 1978 - The evolution of enhanced U234/U238 activity ratios for dissolved Uranium and ground water dating. U.S. Geol. Sur. Report 78-701.

CRUZ, W.B. da - 1974 - Alguns aspectos de circulação e salinização de águas subterrâneas em rochas cristalinas do nordeste do Brasil. Sudene, Div. Doc. Hidrogeolog. n. 49, Recife.

GIBBS, R.J. - 1972 - Water chemistry of the Amazon River. Geochim. Cosmochim. Acta, 36; 1061-1066.

JOHNSON, N.M., LIKENS, G.E. and BORMAN, F.H. - 1968 - Rate of chemical wheathering of silicate minerals in New Hamphsire. Geochim. Cosmo chim. Acta, 32: 531-545.

KREYSING, K, , LENZ, R. and RIBEIRO, G.F. - 1973 - Salinização das águas subterrâneas no centro do polígono das secas do nordeste brasileiro. Sudene. Div. Doc. Hidrogeolog. n: 46 Vols. I e II, Recife.

LIVINGSTONE, D.A. $-1963 \ldots$ Chemical composition of rivers and lakes, U.S. Geol. Surv. Prof. Pa. 440G, 1-63.

MOREIRA-NORDEMANN, L.M. - 1977 - Etude de la vitesse d'altération des roches au moyen de l'uranium utilisé comme traceur naturel. $\mathrm{Ph}, \mathrm{D}$. Thesi (Doc.Etat). Université de Paris, France.

MOREIRA-NORDEMANN, L.M. - 1978 - Estimation de la vitesse d'altération des roches par l'utilisation de l'uranium comme traceur. C.R. Acad. Sci. Paris, 287 D 419.
MOREIRA-NORDEMANN, L.M. - 1980 - Use of U234/U238 disequilibrium in measuring chemical weathering rate of rocks. Geochim. Cosmochim. Acta, 44: $103-108$.

MOREIRA-NORDEMANN, L.M. and NORDEMANN, D. - 1980 - In preparation.

OSMOND, J.K., KAUFMANN, M.I. and COWART, J,B. - 1974 - Mixing vo. lumes calculations, source and aging trends of Floridan aquifer water uranium isotopic method. Geochim. Cosmochim. Acta, 38: 1038-1100.

OSMOND, J.K. and COWART, J.B. - 1976 - The theory and uses of natura uranium isotopic variations on hydrology. At, Energy Rev., 14: 621-679.

PINTA, M. et al $-1971-$ Spectrométrie d'Absorption Atomique, Application a l'Analyse Chimique. T2, Masson Ed. Paris.

RIBEIRO FILHO, A. - 1975 - Comportamento do sódio, cálcio, potássio e magnésio nas precipitaçðes atmosféricas na bacia do Paraguaçu, Bahia. MS. Thesis, UFBa, Salvador, Brasil.

RODIER, J. - 1971 - L'Analyse Chimique et Phisicochimique de l'Eau. Dunod Ed., Paris.

SLAVIN, W. - 1968 - Atomic Absorption Spectroscopy - John Wiley, N.Y. SUBRAMANIAN, V. -1979 - Chemical and suspended-sediment characteristics of Rivers of India, J. Hydrol., 44: 37-55.

TRICART, $J$, and CARDOSO DA SILVA, $T$ - 1969 -m Estudos de geomorfolo gia da Bahia e Sergipe. Fund. Desenvolv., Cienc. Bahia, Brasil.

TRICART, J. and CAILLEUX, A. - 1974 - Traité de Geomorphologie - V Le Modèle des Regions Chaudes: Forêts et Savanes. SEDES Ed., Paris 345 pp.

Recebido em 24 de setembro de 1981 . 